services. Although the river also supports a large human population and generates $>30 \%$ of China's GDP, it faces many severe ecological and environmental challenges. China has, however, proposed sustainable development of the whole Yangtze River system. Following visits by President Xi Jinping to Chongqing, Wuhan and Nanjing in the upper, middle and lower reaches of the Yangtze River in 2016, 2018 and 2020, respectively, he decreed that conservation and restoration, and avoidance of excessive development, must become priorities.

In 2020, a 10-year ban on fishing in the Yangtze River was implemented by the Ministry of Agriculture and Rural Affairs, with fishing in all tributaries prohibited. The effects of this ban are already clear in the lower reach of Yuan River, a tributary of the Yangtze River, where a larger population of scaly-sided merganser Mergus squamatus, a prodigious fish-eater, was able to overwinter in 2020 as a result of greater food availability.

The Landmark Yangtze River Protection Law was adopted by the National People's Congress Standing Committee, China's top legislature, on 24 December 2020, and entered into force on 1 March 2021 as the country's first legislation on a specific river basin. This law bans fishing in all natural waterways of the river, and in its tributaries, estuaries and feeder lakes. It consolidates conservation of the Yangtze River and provides a reference for development of legislation for other river basins.

To complement this law, a draft Wetland Protection Law was submitted to the Standing Committee of the National People's Congress on 20 January 2021. It is the country's first national legislation focused on conserving its wetlands. When passed, this second law will prohibit any organization or individual from destroying waterbird habitats and other wetland biodiversity.

PeIZHong LiU (๑ orcid.org/0000-0001-5387-1457),

MEIHAN LIU (৫ orcid.org/0000-0002-7875-3649),

GUANGCHUN LEI (@ orcid.org/0000-0001-9021-5758) and

QING ZENG (๑ orcid.org/0000-0002-7471-4941)

Beijing Forestry University, Beijing, China

E-mail guangchun.lei@foxmail.com

YIYU LI (@ orcid.org/0000-0002-3424-560X) Hunan

University of Arts and Science, Hunan, China

PETER BRIDGEWATER (@ orcid.org/0000-0001-7972-5386)

University of Canberra, Canberra, Australia

This is an Open Access article, distributed under the terms of the Creative Commons Attribution licence CC BY 4.0

\section{Rediscovery of rare shovelnose sturgeons in the Amu Darya River, Uzbekistan}

The small Amu Darya shovelnose sturgeon Pseudoscaphirhynchus hermanni (Acipenseridae) is a small, rare sturgeon species known only from the Amu Darya River in Central
Asia. It was last caught in 1996, in the middle reaches of the river (Salnikov et al., 1996, The Sturgeon Quarterly, 4, 10-14), and had not been recorded in its lower reaches since 1982 (Zholdasova, 1997, Environmental Biology of Fishes, 48, 373380). After the drying of the Aral Sea, habitat alterations in the Amu Darya River (overfishing, damming and channel management, extraction of water for irrigation, and water pollution) have led to a severe decline of sturgeon species there. In 1996, P. hermanni was categorized as Critically Endangered on the IUCN Red List.

On three occasions in 2020 (18-21 January, 14 March and 3 August), we searched for this species in the lower reaches of the Amu Darya. In a $55 \mathrm{~km}$ stretch of the river in the Khorezm Region of Uzbekistan, we collected five fish with the typical morphology of $P$. hermanni (i.e. a dark morph with a short snout). In addition, we caught four individuals of the Amu Darya shovelnose sturgeon Pseudoscaphirhynchus kaufmanni, which is also Critically Endangered. Pseudoscaphirhynchus hermanni can be distinguished from P. kaufmanni by its lack of a caudal filament, lack of spines on the snout, a shovel-shaped snout, pectoral fins with a fold that curls dorsally, and its small size.

Although they are rare and probably declining, our findings confirm that both P. hermanni and P. kaufmanni are still present in the Amu Darya River. Unfortunately, there has been no known reproduction of these species in captivity. Conservation efforts for both species are needed urgently.

BAKHTIYOR SHERALIEV (๑ orcid.org/0000-0003-3966-7403) School of Life Sciences, Southwest University, Chongqing, China

AkBARJON RozImov Faculty of Life Sciences, Urgench State University, Urgench, Uzbekistan

ARNE LUDWIG (๑ orcid.org/0000-0001-7249-9953) IUCN Sturgeon Specialist Group, Department of Evolutionary Genetics, Leibniz-Institute for Zoo and Wildlife Research, Berlin, Germany, and Thaer-Institute, Faculty of Life Sciences, Humboldt University Berlin, Berlin, Germany

Zuogang Peng (๑ orcid.org/0000-0001-8810-2025) IUCN Sturgeon Specialist Group, and Key Laboratory of Freshwater Fish Reproduction and Development (Ministry of Education), Southwest University School of Life Sciences, Chongqing, China.E-mail pzg@swu.edu.cn

This is an Open Access article, distributed under the terms of the Creative Commons Attribution licence CC BY 4.0

\section{Impact of the COVID-19 pandemic on conservation of the Javan gibbon}

The Coffee and Primate Conservation Project was initiated in 2012 to conserve the Javan gibbon Hylobates moloch and its habitat in the western Dieng Mountains, Central Java, 